Volume 12 Issue 4

October 2021

\title{
The COVID-19 Pandemic: Invoking the Famine and Pestilence Clause to be Paired with the Medicine Chest Clause from the Numbered Treaties
}

Carrie Bourassa

University of Saskatchewan, Canada, Carrie.Bourassa@usask.ca

Danette Starblanket

University of Saskatchewan, Canada, Danette.Starblanket@usask.ca

Jennifer Langan

University of Saskatchewan, Canada, jen.langan@usask.ca

Mikayla Hagel

University of Saskatchewan, Canada, Mikayla.Hagel@usask.ca

Sadie Anderson

University of Saskatchewan, Canada, Sadie.Anderson@usask.ca

Marlin Legare

University of Saskatchewan, Canada, marlin.legare@usask.ca

Meghan Chapados

University of Saskatchewan, Canada, m.chapados@usask.ca

Recommended Citation

Bourassa, C., Starblanket, D., Langan, J., Hagel M., Anderson, S., Legare, M., \& Chapados, M. (2021). The COVID-19 pandemic: Invoking the Famine and Pestilence Clause to be paired with the Medicine Chest Clause from the Numbered Treaties. The International Indigenous Policy Journal, 12(4). https://doi.org/10.18584/iipj.2021.12.4 


\title{
The COVID-19 Pandemic: Invoking the Famine and Pestilence Clause to be Paired with the Medicine Chest Clause from the Numbered Treaties
}

\begin{abstract}
Treaty-based strategies are required to address the unique needs of Indigenous communities in Canada during the COVID-19 pandemic. A treaty-based approach should recognize provisions within the Numbered Treaties, including the Famine and Pestilence Clause and Medicine Chest Clause, agreed to during the signing of Treaty 6 in 1876. The Famine and Pestilence Clause established the Crown's obligation to aid Indigenous Peoples within Treaty 6 Territory in the event of calamities such as locust raids, storms, starvation, and disease. The Medicine Chest Clause instituted the means through which the Crown would provide medical care for Indigenous Peoples within the jurisdiction. The Government of Canada has a legal obligation to invoke the Famine and Pestilence Clause and Medicine Chest Clause in a strategy to address the spread of COVID-19 in Indigenous communities.
\end{abstract}

\section{Keywords}

COVID-19 Pandemic, Indigenous Peoples, Famine and Pestilence Clause, Medicine Chest Clause, Calls for Action

\section{Creative Commons License} (c) $(1) \Theta \Theta$

This work is licensed under a Creative Commons Attribution-Noncommercial-No Derivative Works 4.0 License. 
Bourassa et al.: The COVID-19 Pandemic

\section{The COVID-19 Pandemic: Invoking the Famine and Pestilence Clause to be Paired with the Medicine Chest Clause from the Numbered Treaties}

The spread of the COVID-19 pandemic has the potential to create lasting negative health outcomes for First Nations communities. In the context of this article, First Nations communities are defined as a community on Treaty Territory that is inhabited and governed by First Nations people. First Nations are one of three groups of Indigenous Peoples (along with Inuit and Métis) of what is now Canada. First Nations are the only Indigenous identity group that signed Treaties with the Crown and belong to larger tribal groups recognized by the Government of Canada as "Status Indians" (Indigenous Foundations, 2009).

We began the first draft of this article in March 2020 as the First Wave of COVID-19 began in Canada. The virus eventually spread throughout Canada, including into Indigenous communities. The Government of Canada was accused of failing to address the needs of Indigenous communities quickly enough; instead, they indicated that they would monitor communities and respond as needed. In fact, the Indigenous Services Minister was not appointed as a permanent member of the COVID-19 committee, for which Prime Minister Trudeau was later criticized (Forester, 2020). The Government of Canada has since committed CAD $\$ 305$ million dollars in emergency funding to Indigenous communities in Canada (Palmater, 2020). This money will go to 634 First Nations communities, and a vast number of Métis and Inuit communities. The Government of Canada has announced this funding will flow through Indigenous Services Canada (ISC), but communities have cause to be concerned because of the history of bureaucratic challenges in accessing funding coming out of ISC. In addition, ISC (2021) has proposed to provide CAD $\$ 1.2$ billion to Indigenous communities over the course of 2021 to 2022 for COVID-19 response measures.

Canada is in a state of emergency and timing is critical in this crisis situation. A First Nations-specific strategy to meet the anticipated needs of communities, including a concrete plan on how funding should be distributed, must be implemented. The funding amount must be relevant and based on aspects of equity rather than equality. The need for this funding is based on the pre-existing relationship between the Government of Canada and the First Nations peoples in Canada, a fiduciary relationship created from the treaty period, and as a result of treaties.

The treaties in Canada were negotiated with "Indian" Nations (now referred to as First Nations) in order to open up the land for settlement (Asch, 1997; Jorgenson, 2007; Poelzer \& Coates, 2015). In exchange, certain provisions were offered, and others were requested by First Nations negotiators on behalf of their people (Cardinal \& Hildebrandt, 2000; Jorgenson, 2007). Importantly, the Indigenous Peoples who signed Treaty 6 secured provisions that were vital to their well-being:

Treaty Six is unique because a number of eyewitness accounts of the negotiations were recorded and later published. These accounts contradict the official accounts published by Treaty Commissioner Morris and emphasize the agency of the Chiefs who managed to expand the treaty terms beyond what had been authorized by the Canadian government, including protection from disease and famine, the medicine chest clause, and assistance in the transition to agriculture. (Krasowski, 2019, p. 176) 
Provisions, such as the Famine and Pestilence Clause, committed the Crown to providing relevant and necessary assistance to First Nations who signed the Treaty in the event of a national calamity (Morris, $1880 / 1991)$. In the event of a natural disasters or disease outbreak, First Nations could request assistance, and the government was supposed to come to their aid and ensure the community was protected. According to Miller (2007), "the 1876 treaty responded to the worsening conditions on the Prairies with clauses dealing with famine and health care” (p. 179). However, even after the Treaty was signed, disease and sickness continued to spread within the communities, in large part because government officials, including Indian Commissioner Edgar Dewdney, knowingly gave rotten food to them (University of Alberta Faculty of Law, 2018).

Treaty 6 contained the Famine and Pestilence Clause and Medicine Chest Clause. These two clauses must be considered together when looking at the current crisis because they are intertwined and were negotiated in 1876 with the intent that they would be paired. The Famine and Pestilence Clause and Medicine Chest Clause were intended to ensure the First Nations under the Treaty would not suffer as a result of contact with the newcomers. After the treaties were signed, however, First Nations continued to face health challenges. The ongoing impacts of colonialism have resulted in First Nations populations, both on-reserve and off-reserve, being at higher risk of disease than non-Indigenous peoples.

The treaty relationship created when the Famine and Pestilence Clause and the Medicine Chest Clause were agreed upon is highly relevant to the current pandemic circumstances and must be fully understood in order to address the unique health needs of First Nations peoples. As the name suggests, the Medicine Chest Clause signified a guarantee that the Indian Agent, the government official designated to implement policies regarding First Nations, would keep a medicine chest for use by the people residing in the territory. The Treaty has been modernized and amended since its original signing in 1876 at Fort Carlton, Saskatchewan, and the Medicine Chest Clause was amended to include an additional clause stating that relevant relief must be provided in the case of overwhelming pestilence or famine (Beal, 2020).

The Famine and Pestilence Clause came in as part of the Medicine Chest Clause and at the same time. While the Medicine Chest Clause eventually translated into provincial health care to be delivered to Indigenous Peoples and settlers in the provinces and territories in Canada, these services have no recognized affiliations with the Famine and Pestilence Clause. Health care services for First Nations people on reserve are an exception to provincial jurisdiction. These services are delivered through federal mechanisms.

When health issues put First Nations people at risk, the Famine and Pestilence and Medicine Chest Clauses legally obligate the Government of Canada to assist First Nations people under Treaty 6 without delay. The spread of the COVID-19 disease, caused by SARS-CoV-2 infection, necessitates the Famine and Pestilence Clause and Medicine Chest Clause in order to address the emergency needs of First Nations communities. The Assembly of First Nations (AFN, 2020), the political organization representing First Nations nationally, along with numerous provincial and municipal jurisdictions (Canadian Press, 2021) have declared a state of emergency as a result of COVID-19. As outcomes of this COVID-19 pandemic are still unknown, and there is no end in sight, Indigenous Peoples in Canada have the right to be confident their needs will be met in the form of a strategy that includes funding and support from the federal government now and over the next several months and perhaps years. 
In many First Nations communities, health is understood as a balance between the mental, emotional, physical, and spiritual aspects of a person (Bourassa et al., 2004). First Nations peoples' health is connected to Canada's history of colonization, resulting in a multitude of health challenges and inequities since contact (Bourassa, 2010). These health challenges include the impacts of a lack of cultural safety, inadequate access to health services, remoteness, and migration into urban centres. The history and ongoing effects of colonization have led to First Nations people having lower average socioeconomic status (Palmater, 2020). With the increased migration to urban centres starting in the 1960s, First Nations peoples experienced changes to their socioeconomic conditions, including homelessness, addictions, the apprehension of children into the child welfare system, higher rates of incarceration, and increased levels of poverty. The impacts of residential schools and the Sixties Scoop added to these challenges and created health issues for First Nations peoples. As was emphasized in the reports of the Truth and Reconciliation Commission of Canada (2015) and the Royal Commission on Aboriginal Peoples (1996), these colonial institutions and policies have led to many ongoing health concerns in Indigenous communities. Further, Indigenous Peoples are not provided the same access to health care services and delivery as non-Indigenous peoples in Canada (Forester, 2020). Recently a class action lawsuit was launched for abuse and mistreatment of patients who attended federally run Indian hospitals:

The statement of claim alleges that First Nations, Inuit and Métis patients - including many children - faced substandard health care, physical and sexual abuse, along with forcible confinement to beds at Indian hospitals, which were run by the federal government across the country. There are at least 29 Indian hospitals covered by the proposed class action, which covers 1936 to 1981. Many of the patients sent to Indian hospitals were treated for tuberculosis, and some have alleged that they were the subject of medical experiments. The federal government passed a law that allowed bureaucrats with the department then known as Indian Affairs to forcibly admit Indigenous people to the hospitals who were suspected of having contracted the infection. (Barrera, 2020, paras. 9-12)

While attending residential schools and Indian hospitals, Indigenous people were subject to numerous unethical research projects (Pelley, 2020). Mosby's (2013) research made public the nutritional experiments that took place in residential schools. This history of unethical medical experiments is relevant as it has caused suspicion and mistrust amongst Indigenous people regarding immunizations, vaccinations, needles, and medical professionals and other care providers.

Some specific health challenges resulting from this history are, for the most part, unique to First Nations peoples. They are based on numerous experiences with lack of access to health care and inequities in the healthcare system, along with the treaty relationship. The impoverished socioeconomic conditions faced by First Nations peoples, which are demonstrated in data that is already well known to the Government of Canada and Canadians generally, further compounds the crisis.

The substandard living conditions created by the Indian Act have continued to impact Indigenous Peoples in Canada. The 1880s brought health challenges to Indigenous people, such as chronic infectious conditions such as tuberculosis and whooping cough, which are exacerbated by overcrowding in homes as well as lack of access to nutritious food and medicine. Indian agents noted the various incidents of diseases, such as the misdiagnosed "land scurvy" (which was actually a glandular infection 
associated with tuberculosis known colloquially as "scrofula"), sweeping through the First Nations populations on reserve. The increase in diseases among Indigenous Peoples has been found to be the direct result of malnutrition causing weakened immune systems and lack of protective immunity (Lux, 2001). This malnutrition was caused by food insecurity and changes in diet that occurred because of colonization. Concerns around food safety and food security continue to exist in most communities today.

The compounding effects of malnutrition, overcrowding, and exposure to novel diseases had a devastating effect on Indigenous Peoples upon initial contact (Lux, 2001). In order to prevent epidemics and diseases from continuing, First Nations leaders negotiated a clause that would protect them from any impending or subsequent crises. The Office of the Treaty Commissioner (2007) documents speak to this clause:

During the 1880s and at other times, severe famine struck Treaty First Nations across southern Saskatchewan. The Crown was obliged to assist them under treaty provisions and Crown promises, yet officials used the rationing of food to weaken the First Nations politically and splinter their ranks. Once settled on reserves, they suffered chronic malnutrition as the result of rationing policies that in some cases led to death from starvation and susceptibility to disease. Their pleas were all too often ignored by Agents and officials in Ottawa, who had the means and the power to provide, or withhold, relief. (p. 42)

Despite facing famine and food rationing, Indigenous Peoples were not weakened. Their cultures, ceremonies, and traditions remain vibrant (Manuel \& Derrickson, 2015; Million, 2013). Indigenous Peoples have demonstrated incredible resilience through their history with the Crown. However, as broken agreements have harmed Indigenous Peoples, a prompt and relevant response is expected from the Government of Canada in response to the ongoing global COVID-19 pandemic.

Colonization introduced novel diseases to Indigenous populations that had not previously been exposed (Coletta \& Traiano, 2020; Kelton, 2015). As colonization continued and inequities were exacerbated, those previously unexposed to diseases like smallpox and influenza were prone to devastating epidemics. Kelton (2015) stated, "Europeans were the opponents, and diseases served as their unwitting weapons" (p. 8). The Spanish flu epidemic of 1918 caused an estimated 4,000 deaths of Indigenous people in Canada, or 37.7 deaths per 1,000 people (Lux, 2001). Comparatively, non-Indigenous people only faced 6.5 deaths per 1,000 people. When comparing death rate statistics between Indigenous and nonIndigenous people during the 1918 epidemic, and more recently the H1N1 Pandemic of 2009/10 (swine flu), the need for relevant support from the federal government for the current pandemic becomes clear. In order to avoid history repeating itself in terms of death rates, definitive action must be taken by federal authorities to provide a culturally relevant solution based on historic treaty obligations.

The frequency of Indigenous people having lung infections, such as tuberculosis, combined with lower average health status and chronic health conditions, puts First Nations in an even more precarious position during this COVID-19 pandemic. Individual behaviours, such as tobacco smoking, and differences in the availability of services that necessitate, for example, the use of wood burning stoves for home heating, further compounds the risk for many. Critical environmental factors in First Nations communities, such as poor infrastructure and overcrowded housing conditions, as well lack of safe water 
and food, all contribute to the potential for the COVID-19 pandemic to escalate at rates higher than that of the non-Indigenous population. Indigenous people in the United States are also expressing similar concerns that segments of their population are particularly vulnerable as a result of the history of colonialism (Deerinwater, 2020).

A recent environmental scan illustrated that First Nations peoples are at high risk for contracting infectious diseases. In 2019, the Morning Star Lodge partnered with the File Hills Qu'Appelle Tribal Council (FHQTC) to bring a diverse group of Indigenous community members to the Knowing Your Health Symposium in Fort Qu'Appelle, Saskatchewan, to learn about traditional health and to engage in a constructive dialogue regarding Indigenous health and wellness. Indigenous research methods and community-based involvement informed and framed the research project. With the involvement of the Community Research Advisory Committee and community health directors, an environmental scan was conducted, through an anonymous survey distributed to more than 100 respondents at the Symposium, to learn more Indigenous Peoples' health concerns. Researchers engaged with Indigenous Peoples to learn about and gather baseline data on health behaviours, particularly nutrition, exercise, and selfmanagement of health and the relationship to cognitive function and dementia. The findings provided a complex overview of the health of Indigenous Peoples and identified issues in access to health care and health services, a high incidence of multi-morbidities including diabetes, heart disease, high blood pressure, and depression. When it comes to implementation of treaty obligations, the Government of Canada has an ethical obligation to address existing health issues as well as a legal obligation under the treaties (Saul, 2014).

The treaties "are unique and have a distinct place in Canadian law" (Public Legal Education Association of Saskatchewan, 2007, p. 5). The parties created a reciprocal relationship based on both trust and fiduciary obligations. Indigenous Nations shared the land with the Crown with the expectation that the Crown would nurture this relationship. For the First Nations who agreed to the Treaty, the use of the Sacred Pipe during the treaty negotiations implied that the Nations were placing their trust in the Crown to adhere to their treaty promises, including the financial obligations of the Crown.

There exist a number of legal instruments that should implicate the Government of Canada in addressing historical and contemporary inequities of First Nations peoples. These include the Royal Proclamation of 1763, the British North America Act of 1867, the Numbered Treaties (1871-1921) and the Constitution Act of Canada of 1982. These legal instruments outline the legal obligations of the Government of Canada (and the British Crown before them) to commit and flow financial and other resources as identified by Indigenous communities.

The Royal Proclamation of 1763 set the basis for treaty making and recognizing Indigenous ownership of the land, sovereignty, and nationhood. The Proclamation established that Indigenous Peoples had inherent rights and that they could not be "molested or disturbed on their land" (Office of the Treaty Commissioner, 2007, p. 22). This recognition of rights and land ownership compelled the government to enter negotiations with Indigenous Peoples for access to their lands. The form of nationhood set out in the Royal Proclamation recognized the unique relationship between the Crown and Indigenous Nations. The principles of the Royal Proclamation are entrenched in Section 35 of the Constitution Act of 1982, which states that existing Aboriginal and Treaty Rights must be recognized and affirmed. This 
includes the provisions in the Numbered Treaties, such as the Famine and Pestilence Clause and the Medicine Chest Clause of Treaty 6.

The British North America Act of 1867 made Indigenous Peoples a federal responsibility: Section 91(24) stated, the federal government was responsible for "Indians and lands reserved for the Indians" (see also Krasowski, 2019). According to the Act, the Government of Canada was then responsible for entering into land sharing agreements with Indigenous Peoples. Consequently, it is the Government of Canada that must address, without delay, the needs of the First Nations population in this pandemic. The Government of Canada was quick to address the needs of small business and other cohorts of people but were slow in responding with a specific strategy for First Nations peoples in regard to the COVID-19 pandemic (Hosgood, 2020).

The Numbered Treaties signed between 1871 and1921 included many provisions. Two that are especially relevant to implementing a treaty-based pandemic strategy are the Famine and Pestilence Clause and the Medicine Chest Clause. First Nations negotiated both clauses as part of Treaty 6 in 1876 as a form of protection or insurance. First Nations within this territory contended that if they allowed the newcomers onto their lands and adopted farming for subsistence, they had to be given protection by the Government of Canada both from natural disasters that might destroy their crops and diseases the newcomers may bring. Advocates of forming the treaty hoped these clauses would provide some assurance to skeptics who advised against allowing the settlement of non-Indigenous people. These clauses further provided First Nation signatories with peace of mind because it provided assurance that future generations would not suffer from the decisions they had made. The Famine and Pestilence Clause and Medicine Chest Clause was grandfathered (applied retroactively) into the earlier Numbered Treaties. The Famine and Pestilence Clause, which, as stated, was put forward so First Nations would not suffer or die because of contact with the newcomers, was to be applied to all treaties in times of calamity. First Nations in Treaty 6 Territory recognized the importance of forcing assurances of protection:

The most significant difference between Treaty Six and the previous numbered treaties was the addition of the medicine chest clause, protection in times of famine, and assistance in the transition to agriculture. ... The addition of these terms reflected the agency of the Chiefs, who were astute negotiators able to extend the mandate of the treaty commissioners. (Krasowski, 2019, p. 275)

In 1873, First Nations were looking for ways to protect themselves against incursions by other nations. For example, they requested the North West Mounted Police (NWMP) be dispatched west to eliminate the American incursion of whisky trading and hunting wolves and bison to make robes. The establishment of reserves was based on this mindset of protecting First Nations from outside threats and incursions, which still applies today, and First Nations communities must be protected during the pandemic. There have already been cases in which non-Indigenous Canadians have attempted to squat on First Nations reserves to protect themselves from COVID-19 (CBC News, 2020). The Government of Canada must make clear to Canadians that they cannot flee to remote reserve locations to escape the pandemic and create policies to protect reserve lands from outside exploitation. 
In 1880 the Crown's treaty commissioner, Alexander Morris, wrote about his experiences with some of the Numbered Treaties, including the Famine and Pestilence Clause. In his address to the First Nations in Treaty 6, he stated:

The Government will not interfere with the Indian's daily life, they will not bind him. They will only help him to make a living on the reserves, by giving him the means of growing from the soil, his food. The only occasion when help would be given, would be if Providence should send a great famine or pestilence upon the whole Indian people included in the treaty. We only looked at something unforeseen and not at hard winters or the hardships of single bands, and this, both you and I, fully understood. (Morris, 1880/1991, p. 241)

Morris also said about the First Nations peoples residing in Treaty 6 territory:

In a national famine or general sickness, not what happens in everyday life, but if a great blow comes on the Indians, they would not be allowed to die like dogs. What occurred in Red River last year from the destruction of crops by the grasshoppers, affected our whole people, and without being bound to do anything, the charity and humanity of the Government sent means to help them. (Morris, 1880/1991, p. 228)

In his text, Morris provides the list of Treaty 6 provisions. Regarding the provision of assistance, he stated:

That in the event hereafter of the Indians comprised within this treaty being overtaken by any pestilence, or by a general famine, the Queen, on being satisfied and certified thereof by her Indian Agent or Agents, will grant to the Indians assistance of such character and to such extent as her Chief Superintendent of Indian Affairs shall deem necessary and sufficient to relieve the Indians from the calamity that shall have befallen them. (Morris, $1880 / 1991$, p. 354)

This Famine and Pestilence Clause was grandfathered into the earlier treaties (Treaties 1 to 5) and those that followed Treaty 6 (Treaties 7 to 11), just as the Medicine Chest Clause was. As the Government of Canada could not apply these clauses to only one treaty, they were applied to all the Numbered Treaties.

According to St. Germain (2005), in examining Treaty 6:

Canada made no explicit written promise to subsist the Plains Cree. The closest that the government came to such a written commitment was the vague and highly discretionary 'famine relief clause of Treaty 6, which promised aid in the event of catastrophe. Even then, however, it was subject to official confirmation and recommendation. (p. 78)

Furthermore, the University of Alberta Faculty of Law (2018) describes how the Canadian government failed to uphold its legal responsibility to Indigenous communities, stating:

The legacy of Treaty 6 is a tragic example of how the colonial powers weakened Indigenous communities to the point that they would desperately give up their rights in return for the promise of survival. It is an example of how even once their rights were given up, the Canadian 
government broke its promises to Indigenous peoples and allowed continued suffering and death in Indigenous communities. (para. 10)

It is important to understand that the treaty negotiations make clear that First Nations peoples were not expecting the Crown to sustain them. However, they did expect provisions in exchange for opening up their land for settlement and allowing newcomers amongst them (Manuel \& Derrickson, 2015; McAdam, 2015).

The literature related to the Famine and Pestilence Clause is extremely limited; however, the spirit and intent of the provisions can be understood from the perspective of First Nations at the time of treaty signing (Angus, 2015; Price, 1991). The Crown, and subsequently the Government of Canada, interpreted the treaties from a literal framework, where what is written is what was agreed to (Asch, 1997), which is why there is so much divergence between government and First Nations interpretations and implementation of the treaty agreements. In the wake of opening their lands to immigration, the First Nations who negotiated the Famine and Pestilence Clause and Medicine Chest Clause were looking for a way to protecting their people from a calamity or a force that could not be prevented, and to safeguard the agreements (i.e., the treaties) into the future. For example, if First Nations were to accept farming, then a disaster such as grasshopper or locust raids or dust storms could potentially wipe out their crops and destroy their means of sustenance-they knew they had to protect themselves against these catastrophes. To First Nations, the Famine and Pestilence Clause would make the Crown responsible for providing assistance in the event of any calamity or disaster that would put First Nations in a weakened state compared to their pre-treaty position.

\section{Discussion and Conclusion}

Following the arrival of SARS-CoV-2, the situation worsened quickly and First Nations peoples in the Numbered Treaty territories were faced with shortages of food and supplies and loss of employment, as well as an existing lack of adequate health care that limited access to testing and housing shortages and overcrowding in homes that increased the risk of household transmission. There is an urgent need to address gaps in pandemic response policies affecting First Nations on and off reserve. Indigenous leaders are concerned about the ongoing waves of this pandemic:

Indigenous leaders from across Canada have been raising alarms about COVID-19, worried that supports promised by the Federal government to help First Nations, Inuit and Métis might not do enough to prevent the most vulnerable people from falling through the cracks. (Wright, 2020, para. 2)

Canada has a history of portraying itself as a humanitarian country (Dhillon, 2017). Canada now has an opportunity to demonstrate their commitment to Indigenous Peoples.

The Ontario Human Rights Commission (2020) released Actions Consistent with a Human RightsBased Approach to Managing the COVID-19 Pandemic with a section pertaining specifically to Indigenous Peoples:

a. Recognize that the impact of COVID-19 will be exacerbated by the ongoing negative impact of colonialism on Indigenous communities and will have a unique, intersectional impact on 
Indigenous women and children, people with disabilities, people with addictions and older persons.

b. Take extra steps and provide funding to protect Indigenous peoples' health and human rights across the full range of social service sectors.

c. Make sure Indigenous and other remote communities have immediate access to clean water.

d. In cooperation with Indigenous peoples, provide assistance to repatriate Indigenous individuals who wish to return to their home communities who are homeless, released from incarceration or other institutional residences and/or are otherwise vulnerable. (Respect the rights of First Nations, Métis and Inuit (Indigenous) peoples section, paras. 1-4).

The Government of Canada and the British Crown are legally obligated to commit and flow financial resources and other support as identified by the First Nations communities. The ways in which these resources are allocated should depend on an engagement plan developed in collaboration with each First Nation community based on their unique situation. Engagement plans should be designed with attention to the community's unique needs and available resources. For example, some Tribal Councils have hospitals or medical centres that can be used as a central location for medical services. In northern communities, people are going out on the land and living off the land, so a diversified engagement plan is necessary. In on-reserve and remote communities the engagement plan will be dependent on factors such as location and size. In urban centres the engagement plan will involve multiple jurisdictions and will need to be designed to accommodate each of them.

An engagement plan for on reserve and remote communities should include the following:

- Mobile testing site and point of care analysis: The establishment of a mobile testing site located on their territory with rapid diagnosis and medical counselling services.

- Field testing equipment: Testing kits to be administered at the mobile testing site and outreach to homes.

- Medical equipment: Ventilators to be set up at the field hospitals with intensive medical care.

- Field hospitals: To be set up within their territories.

- Medical supplies: Respirators, masks, gloves, gowns, face shields, and disinfectant to be made available.

- Vaccinations: Educational outreach, community engagement, and information sessions regarding vaccinations; timely, priority access to the vaccination.

- Cures: Timely, priority access to vaccine and boosters as approved by Health Canada for each sub-population (e.g., children).

- Other resources: As identified by the local health professionals within their health authority in their Traditional Territory.

The leader of the Saskatchewan New Democratic Party (NDP), the official opposition party, criticized the Government of Saskatchewan's lack of adequate support for Indigenous communities who are at higher risk than the mainstream population and called on the government to: 
- Ensure safe housing for on- and off-reserve populations, including capacity for self-isolation;

- Address acute food security concerns in rural and remote areas of the province as supply chains are interrupted and prices rise;

- Increase testing and contact tracing throughout the north, on reserve across Saskatchewan and in urban areas with high First Nations and Métis populations;

- Ensure protections for health care workers, including personal protective equipment (PPE) resources, in already challenging work situations;

- Increase communication with and involvement of First Nations and Métis leaders in decision-making. (Ashley-Hewitson, 2020, paras. 4-8)

The governing Saskatchewan Party has indicated that they have been in contact with First Nations leaders in Saskatchewan but did not provide further detail. The federal government has indicated they have been in contact with the AFN. Whether true engagement has occurred is questionable. The federal government has sent the Canadian military to some remote communities, where necessary, a tactic that has been criticized by some First Nations (Wright, 2020).

In the long term, development of a treaty-based strategy is necessary to ensure the Government of Canada's response is safe and timely in the event of a future public health crisis. As the treaties are legally binding in Canada, it is necessary that the Famine and Pestilence Clause and the Medicine Chest Clause be immediately enacted within policy to implement the spirit and intent of protection the First Nations negotiators intended for their communities. The Famine and Pestilence Clause and the Medicine Chest Clause do not expire; they exist as long as the treaties exist. Honouring these clauses will ensure First Nations communities are protected during the current pandemic and in the future.

\section{References}

Angus, C. (2015). Children of the broken treaty. University of Regina Press.

Asch, M. (Ed.). (1997). Aboriginal and Treaty Rights in Canada. UBC Press.

Ashley-Hewitson, S. (2020, April 3). Sask. NDP calls for increased supports for Indigenous people. 620 CKRM The Source. https://www.620ckrm.com/2020/04/03/sask-ndp-calls-for-increasedsupports-for-indigenous-people/

Assembly of First Nations (AFN). (2020, March 24). Assembly of First Nations declares state of emergency on COVID-19 pandemic [Press release]. https://www.afn.ca/assembly-of-firstnations-declares-state-of-emergency-on-covid-19-pandemic/

Barrera, J. (2020, January 14). Ottawa eyes 'meaningful resolution' to Indian hospitals class action lawsuit. CBC News. https://www.cbc.ca/news/indigenous/indian-hospitals-class-actionlawsuit-1.5425171 
Beal, B. (2020). Treaty 6. In Indigenous Saskatchewan encyclopedia. https://teaching.usask.ca/ indigenoussk/import/treaty 6.php

Bourassa, C. (2010.) The construction of Aboriginal identity: A healing journey. In A. Anderson, W. Kubick, \& M. Hampton (Eds.), Torn from our midst: Voices of grief, healing and action from the Missing Indigenous Women Conference (pp. 75-85). CPRC Press.

Bourassa, C., McKay-McNabb, K., \& Hampton, M. (2004). Racism, sexism and colonialism: The impact on the health of Aboriginal women in Canada. Canadian Woman Studies, 24(1), 23-29.

Canadian Press. (2021, January 25). Grim anniversary: A timeline of one year of COVID-19. CTV. https://www.ctvnews.ca/health/coronavirus/grim-anniversary-a-timeline-of-one-year-ofcovid-19-1.5280617

Cardinal, H., \& Hildebrandt, W. (2000). Treaty Elders of Saskatchewan: Our dream is that our peoples will one day be clearly recognized as nations. University of Calgary Press. https://doi.org/10.2307/j.ctv6gqwq3

CBC News. (2020, March 30). Quebec couple fleeing COVID-19 'endangered' Yukon First Nation, Chief says. CBC News. https://www.cbc.ca/news/canada/north/quebec-couple-old-crowyukon-covid-19-1.5514429

Coletta, A., \& Traiano, H. (2020, March 31). The world's Indigenous Peoples, with tragic history of disease, implore outsiders to keep coronavirus away. The Washington Post. https://www.washingtonpost.com/world/the americas/the-worlds-indigenous-peoples-withtragic-history-of-disease-implore-outsiders-to-keep-coronavirus-away/2020/03/31/98597e3c6f7f-11ea-a1560048b62cdb51 story.html?fbclid=IwAR3CdeaZ7VIGTrwDGPcUi82uTZvJEmHPev7iLxTGT JUBDm5UJWS3qkFDmzA

Deerinwater, J. (2020, April 3). Historic injustices against Native people put them at greater risk of COVID-19. Truthout. https://truthout.org/articles/historic-injustices-against-native-peopleput-them-at-greater-risk-of-covid-19/

Dhillon, J. (2017). Prairie rising: Indigenous youth, decolonization and the politics of intervention. University of Toronto Press.

Forester, B. (2020, March 12). Mixed reactions to government's plan to address COVID-19 in Indigenous communities. APTN National News. https://www.aptnnews.ca/nationalnews/mixed-reactions-to-governments-plan-to-address-covid-19-in-indigenous-communities/

Hosgood, A. (2020, March 16). Northern BC, Indigenous communities in race to be ready for COVID19. The Tyee. https://thetyee.ca/News/2020/03/16/Northern-BC-Indigenous-CommunitiesPrepare-For-COVID-19/ 
Indigenous Foundations. (2009). Terminology. University of British Columbia. https://indigenousfoundations.arts.ubc.ca/terminology/

Indigenous Services Canada (ISC). (2021, January 13). Government of Canada announces further reinforcement of COVID-19 supports for Indigenous communities [News release]. https://www.canada.ca/en/indigenous-services-canada/news/2021/01/government-ofcanada-announces-further-reinforcement-of-covid-19-supports-for-indigenouscommunities.html

Jorgenson, M. (Ed). (2007). Rebuilding Native Nations: Strategies for governance and development. University of Arizona Press.

Kelton, P. (2015). New directions in Native American Studies series: Vol. 11. Cherokee medicine, colonial germs: An Indigenous Nation's fight against Smallpox, 1518-1824. University of Oklahoma Press.

Krasowski, S. (2019). No surrender: The land remains Indigenous. University of Regina Press.

Lux, M. (2001). 'Help me Manitou': Medicine and healing in Plains cultures. Medicine that walks: Disease, medicine, and Canadian Plains Native people, 1880-1940 (pp. 71-102). University of Toronto Press.

Manuel, A., \& Derrickson, R. (2015). Unsettling Canada: A national wake-up call. Between the Lines.

McAdam, S. (2015). Nationhood interrupted: Revitalizing nêhiyaw legal systems. Purich Books.

Miller, J. (2007). Compact, contract, covenant: Aboriginal Treaty making in Canada. University of Toronto Press.

Million, D. (2013). Therapeutic nations: Healing in an age of Indigenous human rights. University of Arizona Press.

Morris, A. (1991). The Treaties of Canada with the Indians of Manitoba and the North-West Territories. Fifth House Publishers. (Original work published 1880) https://babel.hathitrust.org/cgi/pt?id=mdp.39015026613763\&view=1up\&seq=5

Mosby, I. (2013). Administering colonial science: Nutrition research and human biomedical experimentation in Aboriginal communities and residential schools, 1942-1952. Social History, 46(91), 145-172. https://doi.org/10.1353/his.2013.0015

Office of the Treaty Commissioner. (2007). Treaty implementation: Fulfilling the covenant. http://caid.ca/TreImplFulCov2007.pdf

Ontario Human Rights Commission. (2020). Actions consistent with a human rights-based approach to managing the COVID-19 pandemic. http://www.ohrc.on.ca/en/actions-consistent-humanrights-based-approach-managing-covid-19-pandemic 
Palmater, P. (2020, March 25). Canada is ignoring the gendered impacts of COVID-19 on Indigenous women. Canadian Dimension. https://canadiandimension.com/ articles/view/canada-ignoring-gendered-impacts-of-covid-19-on-indigenous-women

Pelley, L. (2020). Mistreated: The legacy of segregated hospitals haunts Indigenous Survivors. CBC News. https://www.cbc.ca/news2/interactives/sh/jTCWPYgkNH/mistreated/

Poelzer, G., \& Coates, K. (2015). From Treaty Peoples to Treaty Nation: A road map for all Canadians. UBC Press.

Price, R. (1991). Legacy: Indian treaty relationships. Plains Publishing.

Public Legal Education Association of Saskatchewan. (2007). Treaties and the law. The PLEA, 3O(1).

Royal Commission on Aboriginal Peoples. (1996). Report of the Royal Commission on Aboriginal Peoples. https://www.bac-lac.gc.ca/eng/discover/aboriginal-heritage/royal-commissionaboriginal-peoples/Pages/final-report.aspx

Saul, J. R. (2014). The comeback. Penguin Books.

St. Germain, J. (2005). Feed or fight: Rationing the Sioux and the Cree, 1868-1885. Native Studies Review, 16(1), 71-90

Truth and Reconciliation Commission of Canada. (2015). Honouring the truth, reconciling for the future: Summary of the final report of the Truth and Reconciliation Commission of Canada. https://ehprnh2mwo3.exactdn.com/wp-content/uploads/2021/01/

Executive Summary_English_Web.pdf

University of Alberta Faculty of Law. (2018). Treaty 6: Famine and Pestilence. https://ualbertalaw.typepad.com/faculty/2018/09/treaty-6-famine-pestilence-and-mistahimaskwa.html

Wright, T. (2020, April 2). Feds poised to call in army to help Indigenous communities fight COVID19. Canada's National Observer. https://www.nationalobserver.com/ 2020/04/02/news/feds-poised-call-army-help-indigenous-communities-fight-covid-19 